311 CLAUS MØLLER JØRGENSEN

Lektor i historie

Aarhus Universitet

\title{
MODERNISME ER NATIONALHISTORIE
}

I K\&K nr. 117 finder man en artikel afMichael Böss med den prægnante titel 'Nationalhistorie efter modernismen' (Böss). Den modernisme der henvises til, er den historiske tolkning af moderne nationer - herunder den danske - som resultat af statsbygnings- moderniseringsog integrationsprocesser og ideologiske reorienteringsprocesser i det lange 19. århundrede efter ca. 1750. Det, der træder i stedet efter modernismen, er en etnosymbolsk tolkning, der ser moderne nationer i forlængelse af etniske samfund etableret i den tidlige middelalder.

Titlen, indholdet og måske ikke mindst retorikken, får det til at fremstå, som om modernismen er et overstået kapitel, og at det er helt indlysende, at det må forholde sig således. Men Michael Böss angiver ikke det forskningsmæssige grundlag for sin tolkning af Danmarks historie, hvilket man vel burde kunne forvente af en peer review artikel. I stedet søger Böss at godtgøre sin tolkning på anden vis. Det sker dels ved at henvise til forskning, som siges at ligge inden for samme tilgang som hans egen, dels ved en delegitimering af det modernistiske standpunkt. Hvad det første angår, kommer etnosymbolismens betydning $\mathrm{i}$ dansk forskning til fremstå noget skævvredet. Når det fx hævdes, at "Firbindsværk Dansk identitetshi- 
storie er i overvejende grad præget af den såkaldt etnosymbolistiske forståelse, som trækker lange linjer tilbage i historien" (Böss 165) må det siges at være forkert. Værket kan ikke tages til indtægt for etnosymbolisme, men er i stedet præget af centrale modernistiske bidrag, og bidrag der afgrænser patriotisme i 1600-tallet til samfundets elite og til 1700-tallets borgerskab (Feldbæk; Rerup. Se også Lind 93), hvilket ikke svarer til etnien i Böss' forstand. Ligeledes er historiker og etnolog Palle O. Christiansen, som også siges at være en del af et opgør med modernismen, i virkeligheden modernist (Christiansen). Oplysninger som disse er med til at give etnosymbolismen en forskningsmæssig tyngde, som den ikke har. Hvad delegitimeringen af modernisterne angår, er det måske banalt at påpege, at etnosymbolisten Böss påviser, demonstrer og viser, mens modernisterne alene hævder, påstår og afviser, hvis de da ikke indrømmer, de tog fejl. Denne måde at dikotomisere sprogbrugen, gør det på den ene side let at se, hvem der efter Böss' mening har sandheden på sin side, men på den anden synes det også at implicere, at modernisterne ikke har reelle-læs videnskabelige - hensigter. Dette indtryk understøttes af, at modernisme beskrives som ortodoksi, og indirekte knyttes til et opgør med historiefaget som empirisk videnskab (Böss 161ff).

Dette er det 'videnskabelige' belæg mod modernismen. Empirisk baserede forskningsresultater og tolkninger af Danmarks historie henvises der til gengæld ikke til. $\mathrm{K} \& \mathrm{k}$ har ikke ønsket at publicere en artikel byggende på sådanne forskningsresultater, der viser de mange svagheder og fejl, som Böss' tolkning er behæftet med. Men det kan vises, at statsbygningsprocessen ikke forløber, som Böss tror. Böss' forestillinger om læsefærdighed, identifikationsmønstre i det før-moderne samfund og borgerrettigheder i 1700-tallet er forkerte, og den underliggende idé geografisk kontinuitet i det etniske samfund ugennemtænkt. Principielt må man være kritisk over for den nærmeste ahistoriske forestilling om de store europæiske fortællinger som historiske aktører. Brugen af disse store fortællinger til at skabe kontinuitet, som får den nationale integrationsproces i det 19. århundrede til at fremstå som en selvfølgelig forlængelse af de forudgående århundredes udvik- 
ling, støder imod en faghistoriske konsensus om, at det 19. århundredes modernisering forudsatte det før-moderne samfunds opløsning (for en forskningsbasered modernistisk tolkning se Møller Jørgensen). Og jeg ville i det mindste gerne have haft henvisninger til den historiske forskning, som Böss' faktuelle udsagn og tolkninger bygger på. Det er efter min mening ikke overbevisende alene at bygge på 'likes' i form af historikere, der er blevet overbevist om etnosymbolismens fortrinligheder $\mathrm{i}$ al almindelighed. Modernismen har sine blinde vinkler, den kan revideres og måske også opgives, hvis der kan gives overbevisende empirisk forankrede alternativer. Det vil i det mindste kræve en kvalitativt anden forskningsmæssig fundering, end den Böss har leveret i sin artikel. Retorikken i en videnskabelig artikel må selvfølgelig være en smagssag. Men for mig at se er der nærmest et inverst forhold mellem på den ene side den retorik Böss betjener sig af, og på den anden side den forskningsmæssige tyngde og det faktuelle belæg, som hans artikel bygger på. Etnosymbolismen har endvidere ikke den tyngde blandt historikere, som Böss lader formode, ligeså lidt som den implicitte sammenkædning af modernismen og opgøret med historie som empirisk videnskab forekommer rimelig; efter at have læst artiklen synes det snarere at være etnosymbolismen i Böss' danske aftapning, der bør tildeles den tvivlsomme ære.

\section{LITTERATUR}

Böss, Michael. "Nationalhistorie efter modernismen: folkebegrebet i lyset af Europas store fortællinger", K\& K nr. 117 (2014): 159-174.

Christiansen, Palle. O. "Efterskrift. Perspektiv til dagens debat". I Palle O. Christiansen (red.). Veje til Danskheden. København: Gyldendal 2006, 155-161.

Feldbæk, Ole. "Skole og identitet 17891848. Lovgivning og lærebøger". Ole Feldbæk (red.). Dansk Identitetshistorie bd. 2. København: Hans Reitzels Forlag 1992, 253-324.

Møller Jørgensen, Claus. "Statsbygning, etnosymbolisme og Danmarks historie i 1700-tallet", Historisk Tidsskrift bd. 117:1 (2017), 119-146.

Lind Gunnar. "Gamle patrioter. Om kærlighed til fædrelandet i 1600-tallets Danmark". I H. Jeppesen (red.). Søfart, politik, identitet. Kronborg: Falcon 1996, 91-115.

Rerup, Lorenz. "Fra litterær til politisk nationalisme. Udvikling og udbredelse fra 1800-1845". I Ole Feldbæk (red.): Dansk Identitetshistorie bd. 2. København: Hans Reitzels Forlag 1992, 325-390. 
SVAR

\section{Misforståelser om etnosymbolismen}

Claus Møller Jørgensen (CMJ) har skrevet et kritisk indlæg imod en artikel, hvori jeg forholdt mig skeptisk over for modernismens tese om, at der fra ca. 1750 sker et brud med det førmoderne samfund, som bl.a. fører til dannelsen af begreber folk og nation, som ikke fandtes tidligere. Jeg vil svare på hans indlæg, fordi det desværre bygger på fejl og misforståelser.

CMJ bryder sig ikke om, at min "retorik" i artiklen her og dér har et strejf af polemik over sig. Det fortryder jeg ikke, for "retorikken" skyldtes ganske enkelt, at formålet med selve $\mathrm{K} \& \mathrm{ks}$ temanummer var at lægge op til en diskussion af "historiens genkomst". Og CMJ viger sandelig ikke selv tilbage. Hans svar bevæger sig tilmed på grænsen til det fornærmede og fornærmende.

CMJ mener således, at jeg ved for lidt om danmarkshistorien og specielt historiografien om den. Det har han dog ret i, for jeg har aldrig påstået at være ekspert i dansk historie. Mine forskningsområder er De Britiske Øers og Canadas historier, og derudover er jeg gene- ralist med interesse for historieteori. Artiklen var da heller ikke tænkt som en empirisk påvisning af kollektive ("folkelige") identiteter i førmoderne dansk historie, og jeg medgiver, at det var en fejl af mig at skrive, at fembindsværket om dansk Identitetshistorie er "overvejende etnosymbolistisk". Det har jeg ved genlæsning af udvalgte artikler konstateret ikke at være tilfældet. Men min viden om irsk, engelsk og skotsk historie kan dog bidrage til at kvalificere en diskussion, som bliver lidt for snæver, hvis den kun foregå på præmisserne af dansk nationalhistorie.

Jeg havde to ærinder med artiklen: For det første at lægge op til en teoretisk diskussion om modernismens "kortsyn" på dannelsen af nationer, og derfor, for det andet, at påvise, hvordan forskningen i middelalderhistorie igennem de sidste 40 år har kastet et lys ind over perioden, som burde få modernistiske historikere til at opgive tesen om, at der skete et klart brud mellem før-moderne og moderne historie, hvad gælder kollektiv identitet. Min egen opfattelse er, at perioden fra middelalderen til de moderne samfund er præget af nogle materielle og immaterielle faktorer, der forandrer de kollek- 
tive identiteter, og at man derfor må regne med flere forskellige folk og "nationale" fortællinger. Dette er tilfældet i mange europæiske kongeriger, og jeg ser den samme udvikling i dansk historie.

CMJ's kommentarer bærer desværre præg af nogle alvorlige forståelsesfejl i forhold til etnosymbolismen, som dels ikke er en decideret teori, men snarere en retning, dels ikke bør blandes sammen med hverken priomordialisme eller perennialismen, sådan som $\mathrm{CMJ}$ synes at gøre det. Kontinuitet i etnosymbolismen betyder altså ikke, at kollektive identiteter forbliver de samme over tid. Etnosymbolister anerkender således moderniseringens betydning. Anthony D. Smith har tværtimod klart gjort opmærksom på, at moderniseringen af de europæiske samfund havde stor betydning for folke- og nationsbegrebet, og at de såkaldte paradigmer bør kombineres. I Nationalism and Modernism skriver han:

Vi kan forestille os fremtidige scenarier med i det mindste delvis teoretisk enighed, hvor nogle af forskningsparadigmernes indsigter og formodninger vil kunne kombineres på en frugtbar måde. Men det kan kun ske, hvis man accepterer de nære forbindelser mellem etnicitet og nationalisme og perennia- listiske historikeres argument om, at nogle nationer og deres særlige nationalismer har eksisteret langt tidligere end moderniteten (hvordan den end defineres). Det betyder igen, at vi må afkoble nationer og specifikke nationalismer fra "moderniseringen". Samtidig har modernisterne bestemt ret i at insistere på, at mange nationers moderne karakter. Modernitetens betingelser favoriserer helt oplagt replikationen af nationer, nationalstater og nationalismer i alle dele af verden. Dette ville også tillade os at acceptere etnosymbolismens tese om, at de fleste nationer er opstået på baggrund af forud eksisterende etniske bånd og følelser, også selv om de med tiden bevæger sig langt ud over dem, og deres nationalismer nødvendigvis bruger de etniske symboler, minder, myter og traditioner, som er mest i genklang med flertallet af det navngivne folk, som de ønsker at mobilisere. (Smith 226)

Smith opfordrer derefter historikere og samfundsforskere til at foretage komparative undersøgelser af seks institutionelle dimensioner, som efter etnosymbolisters opfattelse har påvirket dannelsen af både før-moderne og moderne folk: (1) stat, (2) territorium, (3) sprog, (4) religion, (5) historie og (6) ritualer og ceremonier.

Læg mærke til, at Smiths første dimension er "stat". Det er da 
også helt forkert, når cMJ påstår, at jeg ser bort fra statsbygnings- eller moderniseringsprocessers betydning for kollektivers dannelse. Det gør jeg bestemt ikke. Men jeg isolerer heller ikke statsbygning til 17- og 1800-tallet. Der skete også statsbygning i middelalderens kongeriger, men da "staterne" dengang var bygget op omkring kongerne og deres territorialt løse riger, var der naturligvis dengang tale om helt anderledes kollektive identiteter end i 1800 -tallet.

CMJ har desuden misforstået, hvad jeg og andre etnosymbolister forstår ved en "etni" eller et "etnisk samfund". Det ville være forkert at betragte middelalderens etniske grupper som ikke-hierarkiske samfund, hvor alle medlemmerne delte de samme forestillinger og fortællinger om sig selv. De magtfulde var ikke kun stærke i kraft af deres fysiske magt, men også i kraft af at være den tids "symboleliter". Saxo Grammaticus var en del af denne symbolelite, og han var som bekendt leveringsdygtig i netop de historiske fortællinger, som de danske konger havde behov for at styrke deres eget og deres riges internationale omdømme. Hans beretninger tyder dog på, at kongefortællingerne var kendt i befolk- ningens lavere lag. Måske har han ret $i$, at der også fandtes en kollektiv bevidsthed i de lavere samfundslag om at udgøre et folk, der stod bag kongen. En analyse af Gesta Danorum tyder på det (Wagner). Men det kan ikke bevises, fordi der i de lag ikke blev produceret dokumenter.

Hvad etnologerne og antropologerne kan fortælle om traderingen af myter, sagn og fortællinger inden for den mundtlige tradition, bør dog få modernistiske historikere til at åbne øjnene op for, at der også fandtes bred kommunikation af narrativer inden for store kollektiver før Gutenberg. Såkaldt empirisk historievidenskab er alt for dokumentfikseret. Lad mig blot henvise til antropologen Kirsten Hastrups forskning i islandsk middelalder, hvor netop sproglig udvikling og traditionen med at fortælle og siden skrive sit folks historie foruden lovsystemet og geografien (Islands geografiske isolation og helhedskarakter) var afgørende for dannelsen af en kollektiv bevidsthed i 1100-tallet. (Hastrup Culture and History in Medieval Iceland og A Place Apart), som jeg gengiver i min bog Op omkring Island.

Jeg vil derfor fastholde, at modernister har meget at lære af etnosymbolister, antropologer og 
middelalderhistorikere, på samme måde som etnosymbolisterne i 1990'erne lærte af modernisterne og modererede deres tilgangs lidt rigide modsætningsforhold til modernismen. Og på samme måde som Uffe Østergård lærte af Adrian Hasting, da jeg gjorde opmærksom på hans bog i Forsvar for nationen i 2006. Hastings refererer i øvrigt skriftlige kilder, der dokumenterer etnisk-nationale identiteter i højmiddelalderen. Middelalderhistorikere kan således lære os meget om de moderne samfunds rødder. Derfor bør CMJ lade være med at læse mit oplæg til en teoretisk debat som et "opgør" med empirisk historievidenskab. I stedet burde han være åben over for en historisk forskning, der inddrager relevante samfundsvidenskabelige og humanistiske discipliner (herunder diskursteori) og ikke betragte dem som "uvidenskabelige", fordi det ikke er muligt at dokumentere kollektive identiteter i samfundets brede lag i middelalderen. Lad os få en fornuftig teoretisk diskussion af disse spørgsmål og ikke småfornærmede modkritikker.

— Michael Böss

Lektor emeritus

Institut for Kommunikation og Kultur Engelsk, Aarhus Universitet

\section{LITTERATUR}

Böss, Michael. Forsvar for nationen. Nationalstaten under globaliseringen. Aarhus: Aarhus Universitetsforlag, 2006.

Böss, Michael. Op omkring Island. En kulturhistorisk rejsedagbog. København: Gyldendal, 2016.

Hastings, Adrian. The Construction of $\mathrm{Na}-$ tionhood: Ethnicity, Religion and $\mathrm{Na}$ tionalism. Cambridge: Cambridge University Press, 1997.

Hastrup, Kirsten. Culture and History in Medieval Iceland: An Anthropological Study of Culture and Change. Oxford: Clarendon, 1985.

Hastrup, Kirsten. A Place Apart: An Anthropological Study of the Icelandic World. Oxford: Clarendon, 1998.

Smith, Anthony D. Nationalism and Modernism. London and New York: Routledge; 1998.

Wagner, Adam. Danskhed i middelalderen. Aarhus: Munch og Lorenzen, 2015. 
318 KULTUR \& KLASSE * $124 * 2017$ DEBAT 